This is a pre-publication version of the article with the following citation:

Haney, Timothy J. \& Caroline McDonald-Harker. 2017. "The River is Not the Same

Anymore": Environmental Risk and Uncertainty in the Aftermath of the High River, Alberta Flood. Social Currents 4(6): 594-612. Link:

http://journals.sagepub.com/doi/abs/10.1177/2329496516669351

\title{
"The River is Not the Same Anymore": Environmental Risk and Uncertainty in the Aftermath of the High River, Alberta Flood
}

\author{
Timothy J. Haney, Mount Royal University ${ }^{l}$ \\ Caroline McDonald-Harker, Mount Royal University
}

\begin{abstract}
Even when individuals are aware of and well educated about environmental issues like climate change they often take little action to mitigate these problems. Yet catastrophic events, like disasters, have the potential to rupture or disrupt complacency toward environmental problems, forcing individuals to consider the potential effects of human activity on the environment as they expose how environmentally harmful practices put people at risk. This article is based on focus group interviews with 46 residents of High River, Alberta, a rural community hardest hit by the 2013 Southern Alberta flood. It examines if and how experiencing the flood prompted residents to think about the environment or interact with it in new ways. Findings suggest that residents voice a contradiction- while they believe that pre-flood human activity like deforestation, river diversion, and home-building altered the environment and placed communities like their own at risk, they also argue that natural forces like disasters are immune to human efforts to control them. Residents feel their environment is less stable and predicable since the flood, and they worry more about toxicity and associated environmental health risks. The article concludes with a discussion of the implications of these findings for environmental sociology and public policy.
\end{abstract}

\footnotetext{
${ }^{1}$ Corresponding author; Contact: Department of Sociology \& Anthropology, 4825 Mount Royal Gate SW, Calgary, AB, T3E 6K6, Canada. Email: thaney@mtroyal.ca
}

This work was supported by a Partnership Development Grant from the Social Sciences and Humanities Research Council (SSHRC) of Canada under Grant number 890-2013-0135 and a research grant from the Institute for Environmental Sustainability at Mount Royal University. The authors gratefully acknowledge this generous financial support. The authors also thank a number of individuals who have helped to bring this project to fruition: Our team of dedicated research assistants include Alex Christison, Emilie Bassi, Kathryn Wells, Zachary Cox, Kaylea Schwengler, Imogene Roulson, and Sylvia Ulatowski. We also thank our community partners in High River and our colleagues at Mount Royal University for their support and encouragement. 


\section{INTRODUCTION}

Environmental sociologists have long been critical of the tendency to view human activity as separate from ecological processes (Freudenburg, Frickel, and Gramling 1995). In more than 40 years of scholarship, the field has made notable progress in increasing public awareness and understandings of the interconnectedness of ecology and society (i.e., Dunlap and Brulle 2015). Currently, when it comes to environmental issues, like climate change, action lags behind knowledge, often attributed to the public's skepticism about the seriousness of human impacts on the environment because they "lack personal experience with climate change impacts" (Spence et al. 2011; Weber and Stern 2011; Weber 2010). But at particular jarring moments, human dependence on the environment and human vulnerability in the face of extreme environmental changes, may force people to consider the potential effects of human activity on the environment. One such circumstance is experiencing, first hand, a disaster.

Like many nations, Canada has recently experienced an uptick in the number and severity of disasters (Government of Canada 2016), including the 2010 Hurricane Igor in Newfoundland, the 2011 Slave Lake Alberta Wild Fire, the 2011 Goderich Ontario Tornado, the 2013 Southern Alberta Flood and the 2016 Fort McMurray wildfire. However, little is known in a Canadian context about how individuals who reside in disaster-affected communities understand the relationship between human activity and the environment.

Within the disaster literature, research often examines disasters in a recursive fashion, as part of a longer historical sequence and embedded within a social, cultural, economic, and environmental context (i.e., Erikson 1976; Klinenberg 2002), not as 
isolated events. Recent research has begun incorporating a renewed focus on long-term community change following a catastrophic event (Badri et al. 2006; Chang 2010). This commonly results in demographic analyses of the post-disaster community (i.e., Pais and Elliott 2008) and of post-disaster migration patterns (Elliott 2015; Fussell, Sastry, and Vanlandingham 2010). An explicit focus on population dynamics often slights, to some degree, individual-level and social-psychological changes that take place and, at their root, drive the demographic processes. As such, there is still a dearth of knowledge on how disaster-affected residents understand their environment—including its power, stability, and safety. This is a topic of increasing importance as the number of disasters rise, and particularly because public risk perceptions of human impacts on the environment compel or constrain political, economic, social, and individual action to address environmental hazards, such as through environmental policy (Leiserowitz 2006).

This article provides a greater understanding of disaster-affected residents' views of human contributions to risk and increased post-disaster uncertainty by focusing on the recent 2013 Southern Alberta Flood. Our research specifically focuses on people from the town of High River, a small rural community just south of the city of Calgary, known as Canada's energy capitol. The town of High River was the hardest hit by the flood. All 13,000 residents were evacuated, and not allowed to return to their homes for several weeks. The following analyses focus on High River residents' (1) concerns about how human decisions exacerbate risk; (2) enhanced appreciation for the environment and its power; and (3) worries over environmental instability and toxicity.

\section{THE 2013 SOUTHERN ALBERTA FLOOD}


In June 2013, the normally-arid province of Alberta experienced record-breaking rainfall (up to 8 inches in 36 hours) resulting in the Bow and Elbow Rivers, two of the province's largest rivers, overtopping their banks. This triggered catastrophic and unprecedented flooding in Southern Alberta where 32 states of local emergency were declared and the Canadian Armed Forces were deployed to help evacuate 175,000 people, making the event one of the largest evacuations in Canadian history. The Insurance Bureau of Canada subsequently dubbed the flood the costliest disaster in Canadian history (CBC 2013), only recently surpassed by the 2016 Fort McMurray wildfire. The town of High River was the hardest hit by the flood. Water rose over the tops of vehicles, halfway up the sides of the homes, and the streets were no longer accessible other than by boat. Residents scurried to safely evacuate as the water inundated and flooded the town within just hours. All 13,000 residents of High River were evacuated, and the town sat empty. Within the town, 59 percent of the land was inundated by water, over 70 percent of the homes were flooded, and 95 percent of those buildings were moderately to severely damaged (AEMA 2014). High River residents were not allowed to return to their homes for several weeks due to the water, mud, debris, and sewage that submerged the town.

Today, many families continue to be displaced after losing their homes and most of their belongings in the flood. Many High River residents also face continuing social, emotional, and psychological difficulties in the aftermath of the flood. Given severe infrastructural damage, the very town of High River is being completely transformed, with an eye toward future flood risk mitigation.

\section{LITERATURE REVIEW}


Canadians are generally well educated about environmental problems and about climate change. In fact, a recent public opinion poll indicates that 98 percent of Canadians believe that climate change is occurring, and 86 percent believe that human activity is at least partially responsible (CBC 2015). Even those who are aware spend very little time thinking about longer-term environmental change (Norgaard 2011; O'Connor, Bord, and Fisher 1999). As Barr (2008) contends, this is because most of us dedicate our attention to problems that are "here and now," located close to us either spatially or temporally. Problems like climate change, by contrast, seem far off (likely affecting those of future generations) and spatially remote (likely affecting those in faraway places). This inability to connect larger environmental problems to one's everyday world is what scholars often refer to as the "nature-society dichotomy" (Gould and Lewis 2015: 3). As Norgaard (2011) points out, even among the most educated, discussing environmental problems is emotionally difficult and is generally avoided. When asked directly about climate change, her participants were particularly adept at changing the subject, shifting blame to others, or voicing their own feelings of helplessness.

How then might disaster-affected residents conceptualize and understand environmental change? There is reason to believe that experiencing a disaster may enhance environmental reflectivity. According to social theory, long periods of stasis can easily be disrupted by sudden, jarring events—-such as a disaster. This view of time, dubbed "punctuated equilibrium," holds that the most sweeping changes to the status quo happen not slowly and deliberately, but swiftly following watershed events (York and Clark 2006). In short, time is marked by long periods of uneventfulness, followed by brief periods of rapid change. From this perspective, if we hope to understand people's 
views on environmental change, the post-disaster context is an important strategic research site (Drabek 2011). After all, as Johnson and Levin (2009) remind us, "society seems predisposed to preserve the status quo until something goes wrong" (1600). Indeed, recent research does find that "those who report experience of flooding express more concern over climate change...[and] these perceptual differences also translate into a greater wiliness to save energy to mitigate climate change" (Spence et al. 2011: 46; see also Walters et al. 2014). Experience with extreme events has been shown to prompt attitudinal change in other contexts, as well. Haden et al. (2012) demonstrate that farmers who have experienced water shortage were more concerned about climate change and demonstrated an increased intention to adopt mitigation strategies. The disaster literature thus suggests that extreme events can trigger changes in individuals' environmental views, as they necessarily remind us that humans are not, in fact, separate from the environment, nor can we always protect ourselves from environmental events. Though the current study does not utilize experimental data allowing for us to assess whether true change in environmental views occurred, we contend that the flood most likely served as a "focusing event" (Bishop 2014), an event that is sudden and unexpected, predictive of similar future events, and prompts actors to attempt to mitigate future risk. Such events like the 2013 flood or the 2010 BP oil spill, we argue, focus and channel energies toward the causes and consequences of disaster, many of them environmental in nature. This raises an important question: In what ways does a disaster encourage humans to think about and re-think their relationship to the environment? The literature suggests three possible pathways.

First, a disaster may force people to consider how human decision-making 
produces disaster risk. Some literature reveals that whereas many people believe that they are exempt or above natural laws (i.e., Catton and Dunlap 1980; Dunlap and Catton 1979), disasters such as Hurricane Katrina and the Fukishima nuclear meltdown bring into distinct relief the ways in which decisions about land use, development, and resource extraction place residents at risk (see Tierney 2014). This was particularly the case following Hurricane Katrina, where human decisions to alter the environmental landscape to facilitate shipping and petroleum transportation magnified the region's hurricane and flood vulnerability (Freudenburg et al. 2008, 2009). Particularly in these circumstances where human decisions produce or exacerbate risk, previous research has shown that feelings of blame proliferate (Burgess 2012; Erikson 1976; Mcspirit, Hardesty, and Welch 2016), and particularly when coupled with protracted litigation (normally following technological disasters) results in what scholars deemed the "corrosive community" (Picou, Marshall, and Gill 2004). In this light, this paper asks: in what ways do disaster-affected High River residents understand how human decisions produce disaster risk? Do they feel that future vulnerability should be mitigated through continued attempts to engineer the landscape, or do they instead argue for better collaboration with and accommodation of the natural environment?

Second, disaster triggers an enhanced appreciation for the environment. The appreciation, however, is janus-faced. There is scant literature suggesting that disaster helps individuals appreciate the beauty and majesty of the environment (Rung et al. 2011), as well as some suggesting that those affected by a disaster develop a new-found appreciation for environmental power (Tidball 2012) and an increased engagement with their environmental surroundings (Kato, Passidomo, and Harvey 2013; Kato 2013). 
Given this knowledge, this paper asks: How do residents understand the power and the importance of the environment? How do their views on climate change and on industrial reconfiguring of the landscape intersect with these views on the environment?

Third, disaster challenges individuals' belief in a stable and secure environment. As Hawkins and Maurer (2011) point out in the context of post-Katrina New Orleans, one of the most disturbing experiences for residents is the disruption of their ontological security, or their belief in the predictability of their everyday environment, accompanied by the loss of familiar landmarks (see also Giddens 1990). During normal times, this security functions as a "protective cocoon" (Giddens 1991, p. 40). Its disruption, perhaps just as much as the economic losses incurred by disaster, prevent a timely and complete recovery. But, additionally, residents of the post-disaster milieu have good reason to feel less secure in their immediate environment. Much literature demonstrates that postdisaster landscapes suffer from toxic contamination, as flood-water carries oil, petrochemicals, industrial contaminants, and bacteria that can be harmful to human health (Harmon and Wyatt 2008). Compounding this problem is the lack of knowledge made available to the public about actual levels of risk. As Frickel and Vincent (2007) demonstrate, scientific testing for post-disaster contaminants is structured to produce an “organized ignorance." This occurs because the public must believe that experts have properly calibrated their tests (to pick up contaminants at levels where they begin to cause health problems in humans), have tested for all possible contaminants (tests cannot detect what they are not programmed to detect), and will communicate even borderline results efficiently to the public, rather than keeping them hidden in order to avoid inciting "panic." However, as Snider (2004) finds, neoliberal government reforms have drained 
money and resources away from public officials responsible for such testing, as well as for training of these individuals and reporting regulations (often considered bothersome "red-tape" in the neoliberal context). The result is a lacuna of information for local residents who worry that their immediate environment may be contaminated, but do not have the resources to generate and mobilize their own knowledge about environmental risk and contamination. Thus, as Shriver, Adams, and Messer (2014) contend:

"Residents rarely have adequate access to the information needed to reasonably evaluate exposure scenarios and associated levels of harm. When information is made available, elites often present it in such technical language and scientific jargon that it is of little practical use to citizens" (277; see also Kroll-Smith and Couch 1993a)

This occurs because the communities most likely to be contaminated are also those that house the most socially vulnerable and marginalized members of society, both during normal times (Bullard 1990; Lerner 2006, 2010) and following disaster (Picou 2009). While residents harbor many concerns after a disaster, Edelstein (2004) points out that toxic contamination is an "opaque" risk in that it is "neither familiar nor observable, and [its] cause and course are equally obscure" (11). Residents in potentially contaminated communities, he argues, are subject to "lifescape change," characterized by fundamental changes to health, a sense of control, disruption of "home," environmental insecurity, and a loss of trust. As Kroll-Smith and Couch (1993b) argue, such contamination also forces residents to engage in a reappraisal of self, as well as a fundamental altering of relationships to family, friends, and community members. Accordingly, this paper asks: how has the security of High River residents in their environment shifted post-disaster? To what extent, and in what ways, do they feel insecure their new milieu and worry about the health and safety of their surroundings? 
Before investigating these questions, we must note that the investigation takes place in Alberta, an oil-producing region and that economic dependence on oil (which all Albertans experience, either directly or indirectly) has been found to exert an effect on residents' environmental views (Lefsrud and Meyer 2012). This occurs because residents, even after a disaster, worry about their livelihoods (Hamilton, Safford, and Ulrich 2012) and circle the wagons to protect an industry that may be threatened (i.e., Bishop 2014). In the end, those dependent on fossil fuels are less willing to challenge polluters and to speak out against industry practices (Cable and Cable 1995; Malin 2015), though this willingness is often greater for women than for men (Bell and Braun 2010; Bell 2013). Even during non-disaster times, governments (Sodero and Stoddart 2015) and industry (Bell and York 2010; Mix and Waldo 2015) actively work to distract residents from environmentally problematic practices and the energy industry becomes culturally dominant (Bell 2016; Messer, Shriver, and Adams 2015). This is particularly effective in small, rural locations where communities are already vulnerable to attitudinal homogeneity (Marshall, Picou, and Bevc 2005). Prior research also demonstrates that the dependence on oil leads Albertans to adopt a pro-growth, ecological modernization frame to view the environment (Davidson and MacKendrick 2004). Even though our participants did not speak directly about economic fossil fuel dependence in relation to environmental views (as we will show below), it is highly probable that Alberta's dependence on oil, and High River's rural location, exert an influence on the ways that residents conceptualize and relate to the environment, both during normal times and following disaster. 


\section{METHODS}

Prior research indicates that in post-disaster settings it is often advantageous to utilize a qualitative rather than quantitative research methodology due to high levels of participant trauma/vulnerability (Browne and Peek 2014; see Haney and Elliott 2013 for a differing view). A qualitative research approach also allows researchers to build rapport with participants in order to obtain in-depth data, and allows for a greater focus on participants lived experiences, subjective perceptions/understandings, and individual voices. Our research, which utilized a qualitative research approach, consisted of eight separate focus group interviews with key community representatives from the following non-profit organizations in High River, Alberta: (1) The Town of High River; (2) Alberta Health Services; (3) the Foothills School Division and Christ the Redeemer Catholic School Division; (4) Parent Link; (5) Foothills Community Immigrant Services; (6) Foothills Fetal Alcohol Society; (7) Hull Services; and (8) Rowan House Emergency Women's Shelter. A total of 46 individuals participated in these focus group interviews.

The eight focus group interviews were conducted as part of a larger qualitative study that also included 105 face-to-face in-depth interviews with parents who lived in High River and were impacted by the flood. The focus group participants, of which some but not all are parents themselves, worked directly with parents and families in High River both during and post-flood. In addition, the majority of the focus group participants not only worked, but also lived in High River and experienced the flood themselves. As such, many of the experiences shared during the focus groups are based not only on the community representatives' experiences with the clients they serve and 
work with in High River, but also on their own personal experiences as residents of the town. The Human Research Ethics Board at Mount Royal University approved the project, and all participant names have been switched to pseudonyms.

For the purpose of this paper, the term "resident" is used to refer to all of the focus group participants in this study whether or not they resided in High River, because they all worked in High River and therefore they all experienced and/or were impacted by the flood disaster. Additionally, the town of High River is a small, rural, tight knight community where the people who live, as well as the people who work in the town (regardless of where they live) are often considered and referred to as "residents". As such, we have tried to stay true to how the community describes the people who live and/or work in the town by also referring to them as "residents".

The main purpose and advantage of conducting focus groups with key community representatives from these non-profit organizations is that during and post-flood they worked closely and extensively with many residents of High River during the various disaster response and recovery stages. As such these community representatives had numerous interactions with a large number of residents, a wide-range of understandings of the various needs and concerns of residents, as well as expert knowledge about the overall attitudes, perceptions, and experiences of residents in the community.

The focus groups were conducted over a 6-week period from the end of October to mid December 2014, just over a year after the flood. Focus groups ranged in length from approximately 1.5 hours to 2.5 hours. After receiving consent, all focus groups were recorded with the participants' permission, using digital voice recorders, and were subsequently transcribed verbatim. 
Data were analyzed using qualitative techniques that rely on Maxwell's (2005) and Miles and Huberman's (1994) techniques referred to as "descriptive" and "pattern" coding. First, participants' responses were open-coded to identify descriptive explanations of views about environmental issues. These open codes produced numerous concepts that were then put into different categories including: participants' perceptions, understanding, awareness, and concerns, as they pertain to the environment. Second, indepth analysis of these open categories were then conducted in order to identify patterned relationships across these categories in order to determine similarities and differences in the themes. Responses were coded by two research assistants, and then by one of the authors in order to ensure coding reliability. Once coding was complete, arguments were then built by creating an ongoing exchange between the data categories and existing theory in environmental sociology and the sociology of disaster, in an effort to build upon and reconstruct this existing theory (Burawoy et al. 1991: 10).

\section{FINDINGS AND DISCUSSION}

Our data suggest the interplay of three major thematic explanations of participants' postdisaster views of the environment. The findings reveal that personally experiencing a disaster commences a process of reflexivity, whereby individuals begin to contemplate how human action may impact and contribute to larger environmental problems, such as climate change and disasters. However, the research findings also indicate that this awareness does not translate into direct efforts to change and diminish their impacts, partially due to participants' defeatist and fatalistic attitude in their ability to mitigate their human impact on the environment, and also due to the limited tools and resources 
available to them to do so. In the focus groups, High River residents evoke three main discourses to explain their post-disaster environmental views:

(1) Human-produced environmental risk;

(2) The power of the environment and an enhanced appreciation for it;

(3) Insecurity and environmental toxicity.

Below we discuss the three ways that residents articulate their understandings of human-environment interaction in a post-disaster context.

\section{Producing Risk, Driving Environmental Change}

Many High River residents discuss how, since the flood, they are increasingly concerned that human decisions produce disaster risk. Several residents discuss how the human tendency to build against, rather than with and alongside the natural environment has negative impacts and consequences not only for the environment, but also for human habitation. Residents are critical of past and current development practices that the town engages in, which are often done in ways that are seen as fighting against powerful, incorrigible forces. These concerns are illustrated in a statement made by Leanne:

"In terms of clear cut logging, man's influence on the environment, and what it's done to upstream, um, it was just a matter of time before this happened here and anywhere else. You know, where buildings are built and should not be built, as well as the sure impact that humans have on an environment should not be occurring and that's part of the blame in this flood was yeah, Mother Nature and three days of solid rain in one spot, but this was also man made."

One of the human actions that residents commonly discuss as heightening disaster risk is the development and construction of bridges, overpasses, homes, and buildings. Many believe that past building design and placement did not take into consideration the existing ecological layout. Consequently, these human constructions had a negative 
impact on the environment, thus leading to the flood. For example, Meagan explains that within the town there is a common belief that the building of new infrastructure, namely the new overpass that was constructed in 2012 to provide a direct link between a major highway and the town's industrial corridor, changed the flow of the river and decreased the land availability for water absorption. According to her,

"A lot of speculation was around different construction projects that had gone on in town, and how that had altered the lay of the land, and rerouting of the river, etc. We have one parent whose husband is an engineer, and full heartedly believed that the overpass, the construction of the overpass changed the way the river flowed, right, or changed the way the land absorbed the water, and that caused the flood. I don't know if that's true or not, but I think there is definitely!"

Similarly, Miranda echoes this view and also believes that the town's frequent approval of new residential developments in areas where they should have not been approved because of the natural environment.

"I think it's building, I think it's infrastructure. I think it's people possibly interfering with the natural flow of where the river wants to go, and where community municipalities have felt the pressure from local builders where the areas in the northwest that were never supposed to be developed...and you would see these transitions coming through where the mayor of town council will say, no, we're not developing here, and then you would have the local 30-year resident of the community say well I'm a local builder, I can't survive if I'm not able to build a certain way."

Miranda highlights a key theme in both urban and disaster sociology-- the tendency for powerful and influential political actors (builders, developers, and investors) to influence cities' decisions about where and whether to issue building permits. This tendency, perhaps best illustrated in Logan and Molotch's (1987) famous essay about pro-growth elites' influence over civic development, has recently attracted renewed attention. As Tierney (2014) highlights, developers and builders "prefer to operate in environments in which they are not constrained by land use plans, zoning and code requirements, and 
environmental regulations." They also "deemphasize the risks associated with places and spaces, focusing instead on the amenities provided by these locations" (127). Or, as Mileti (1999) argues, the disasters of today are in fact "disasters by design," as they result from key decisions made in the political process many years ago. As Tierney and Mileti both emphasize, and as Miranda points out, decisions about where and how to construct the town of High River placed residents at risk.

Relatedly, residents also commonly discuss the alteration of the landscape with an eye to economic development rather than environmental sustainability as increasing disaster risk. This discussion focuses on specific practices, such as clear-cut logging, and the reconfiguring of rivers both prior to and since the flood. For example Samuel asserts that he now thinks more about the link between economic development and environmental sustainability. He believes that making decisions solely on the basis of economic priorities while neglecting environmental risks is ultimately what caused the flood.

"[Since the flood] I thought more about the debate between economic development and sustainability, I guess, and how that has unfolded here... But how this actually rolled out here in the past twenty years with debates around, you know, the benefits of economic development in these particular areas, and how those priorities outweighed other priorities knowing about the flood risks, which, in some cases, were thought about and ignored because of the benefits in that area. And then of course, down in the future you see what ends up happening. So that debate between economic development and sustainability.....came into conflict here."

Residents often cite clear-cut logging as the most common alteration done to the natural landscape for economic purposes. For example, Robert discusses how clear-cut logging actually induces what he refers to as a "clear cut flood," where barren land left 
after clear-cut logging no longer allows water to infiltrate, and therefore facilitates flooding.

"[The flood] was an unfortunate piece of evidence that makes me feel like I've been working in the right direction with an environmental group, and trying to save water sheds and stuff, and clear cut logging, like I've seen other rivers be totally destroyed by clear cut floods before where there was nothing to hold the water and I'm like, yeah, see!"

Residents also mention the reconfiguring of rivers, both before and after the flood, as a common alteration to the natural landscape, sometimes for economic purposes, but other times as a mitigation strategy following a flood. For example, from 1901 to 2003, the Highwood River, which runs through the center of town, was diverted three different times. Discussion is underway today about yet again diverting the Highwood River, and numerous berms and dikes have already been built. Some residents believe that engaging in development projects or flood mitigation plans that necessitate the reconfiguring of rivers is irresponsible, and is bound to have negative effects. For example, in speaking about these projects, Megan indicates “there's bound to be some repercussions when you start playing with, altering the landscape."

Experiencing the flood commences a process whereby affected people begin to think critically about the larger, more macro-level impacts humans have on the environment, exemplified by processes such as climate change. For example, Mindy states that it is important to pay more attention to the repercussions that human behavior has on the environment.

"I think in terms of our environment, we as a society need to slow down and think about what we're doing before we're doing it, right? We don't need to slap up houses in record speed... we build houses so fast right, and land developers are able to shove through stuff like this right, but did we study where the water would flow?" 
In discussing the effects that humans have on the environment, Natalie also asserts that every human decision and behavior has an impact on the environment regardless of place, space, or time. She states, "I guess every decision they [humans] make is going to have some environmental effect. There, here, or wherever," implying that environmental impact may be inevitable, though geographically varied.

Interestingly, some residents believe that human activity not only contributed to the flood, but may also be related to global climate shifts. For example, Peter describes how although he is not cognizant of the science behind the relationship between human activity, disasters, and climate change, personally experiencing a disaster caused him to "think about climate change" in ways he had not before. Yet on the other hand, he views human intervention on the natural environment, such as building berms around the rivers, as playing a critical and necessary role in protecting people from disasters.

"I thought, I don't know the science behind any of this, but I did think about climate change, and I thought, you know maybe this somehow could be linked to climate change. You know, the changing patterns of rain and so on and so forth. I mean, the mountains are right there, and whether or not the clouds go over, or not, or where it remains and all these kinds of things, I imagine could be affected by climate change...So that's like the big trends of disaster hazards, but then in addition to that, environments, like manufactured environments. Well if there were berms there beforehand kind of thing [before the flood], ... which I mean people wouldn't think of doing, and maybe it's not worth the investment when you can't see what's going to happen down the road until it happens and then you see oh well, cost-benefit! There's a huge benefit of doing it. But man-made, um, human-made, sorry, environments right, and how that plays into the protection of ourselves. Those are two things that I thought about as a result of this flood"

Likewise, Natalie articulates that disasters are becoming increasingly more prevalent and acknowledges that climate change may play a part, despite the fact that, as she states, the town has always flooded, even long before there were discussions about 
climate change. Natalie largely attributes poor zoning and building practices, like building the town next to the river, as exposing residents to increased risk. She expresses frustration at the town's unwillingness to change problematic planning practices despite repeated past flood events.

"'Yeah, the hard part is, if you actually do some research with the history this isn't new, right. It wasn't new, we've flooded lots....And it's not [just] High River, I mean, Calgary flooded, too, right? I mean we built downtown on the Bow [River], we're just lucky it never happened before. So, people want to think it's just environment, like... a hundred years ago global warming wasn't even a word, right, and it flooded back then...I'm sure there's truth to global warming, but this was happening before."

In sum, High River residents believe that human actions and development decisions may be altering the natural environment in ways that put residents at risk.

\section{Appreciation of the Environment and its Power}

Another way that High River residents articulate their relationship to their environmental surroundings is by discussing the ways that the flood changed their appreciation for environmental dynamics. Although High River has a history of seasonal flooding, residents had not anticipated a flood of such magnitude, and were not prepared for the potential power of the event. In their discussions of the flood, residents most often refer to the environment as "Mother Nature", and describe Mother Nature's tremendous force in multiple ways. For example, when discussing the impact that the flood had on the town, Melinda states "Don't mess with Mother Nature"; Jennifer asserts "Mother Nature is angry"; and Meagan goes as far as saying "Mother Earth is on a rampage." Residents view and describe the environment as an uncontrollable and destructive force that humans have no control over, cannot predict, and cannot prevent despite willingness or efforts to do so. In this sense, not only do residents believe that human actions impact the 
environment thus contributing to disaster risk (as discussed in the previous section), but they also link human behaviour to the resulting unpredictability, strength, force, and magnitude of the environment when it is disrupted. For example, Meagan who claimed that "Mother Earth is on a rampage", goes on to discuss how humans have little control over the elements of the environment, despite mitigation efforts and attempts to do so. Humans, therefore, are at the mercy of the earth they are living on, particularly in situations of disaster.

"Ultimately we're very small... we have a very small impact on something like nature and the earth. So, it's really out of our hands. We can just do as much as we can, and hope for the best, really."

The flood prompted residents to not only consider the ultimate strength, but also the destructive ability of environmental dynamics. Residents recognize the increasing human vulnerability to extreme events, and how such major extremes in weather have the power to destroy the means that humans rely upon for day-to-day functioning. For example, Jennifer, in discussing the "power" of "Mother Nature", describes how the flood destroyed all methods of communication within the town, and how this caused her to really consider how environmental change can swiftly disrupt and eliminate humanbuilt technologies, something many of us "take for granted."

"Despite all our technology, there was no communication. I sat at the Fire Hall and the hospital and couldn't talk to the Fire Hall, even if it was on the radio. So, the power of Mother Nature in what we take for granted was absolutely phenomenal in disrupting what we take for granted."

This recognition of the power and destructive ability often times morphs into feelings of helplessness, whereby residents worry about future flooding, but feel it simply cannot be predicted or prevented. For example Meagan describes how, in her view, humans have limited capacity to control the environment. 
"It's a cycle. So, what we do affects the environment, what the environment does affects us....Ultimately you just have to do what's right for us because a flood is not environmentally friendly either, you know, when there's fridges floating down the river and garbage everywhere. So no matter what you do there's always going to be a pro and a con."

Likewise, Deborah echoes this sense of helplessness by stating that completely controlling the environment is not possible, but that human arrogance and hubris have created "expectations" among some that it may be possible, expectations that fell short during the 2013 flood.

"I think what it [flood] made me think about a little more, and just bring to the forefront is that Mother Nature is pretty strong, and....you're never going to be able to actually totally control it..... The thought is that you can control it all 100 percent. No, that's not going to happen. It's an unrealistic expectation."

These reflections on the incorrigibility of the environment are paradoxical of course. While residents believe that human actions have altered the environment and placed people at risk, they also argue that natural forces are immune to human efforts to control them. This paradox partially explains residents' failure to discuss concrete strategies to live in more sustainable ways; residents cannot decide if planners should attempt to control and overtake the environment, or to defer to its power and build only where it allows. For example, Peter discusses this conquer-comply predicament that many residents express.

"It makes me reflect not only here in High River, but anywhere in the world, just wondering, so do we adjust our lifestyles and communities to the weather, or do we adjust the weather to fit our existing communities. Because when I think about, some places, you know, down south, where they're putting houses up eight feet off the ground; and then I think of other places in the mountains where we're making snow so we can go skiing so we're building up the snow artificially; or making artificial containment systems for rivers, and you know, there's the potential as we've seen, for those things to break. So yeah, which do we hit? A middle of the road? Or do we go to one extreme?" 
Residents' discussions of environmental power during the flood are coupled with discussions of a greater appreciation of the environment following the flood. The flood caused many residents who felt separated from the environment to re-embrace it. As such, residents often speak of spending more time outside since the flood, and placing a newfound emphasis on green space. For example, Brenda states that prior to the flood there was an appreciation of George Lane Memorial Park in theory, but not often in practice. Many residents appreciated this natural space prior to the flood, but did not often vocalize their feelings nor utilize the space. However, when the park was restored and reopened a year post-flood, there was a renewed appreciation and an increased utilization of this natural community space, which became symbolic of the town recovery.

"You know, we really appreciate the park now. It's not something we necessarily said we appreciated as much before, even though we did... George Lane Park reopened in August of 2014, and I remember everyone in the office being excited saying "Oh, we're going to go take walks in the park." We hadn't really done that, but we were all so excited for it to reopen. So, maybe more of an appreciation for the natural things we do have in High River."

Similarly, Cassandra discusses how when the park reopened, she had a greater appreciation of this space and its beauty, as well as took the time the time to connect with the environment and enjoy the grass. According to Cassandra,

"Going [to the park] on July 1, and the grass was so beautiful. I just like took my shoes off and ran through the grass, whereas probably like before I probably wouldn't have done that. Because like, ew, what is on this grass? But I knew it was all fresh, and beautiful."

Cassandra and Brenda are using green spaces in ways that are different than before the flood, similar to Kato's (2013) finding that her participants in post-Katrina 
New Orleans embraced gardening and growing food - in both cases the disaster prompted residents to immerse themselves in green space.

In sum, High River residents draw on the power of nature during the flood (i.e., Tidball 2012) alongside the ways that the flood changed their level of appreciation for environmental dynamics (Rung et al. 2011). Even though residents acknowledge the impact that humans have on the environment and the role human decisions played in contributing to the flood, many feel they had and continue to have little control in predicting, preventing, and avoiding disasters. What they do feel they have control over is their appreciation and utilization of natural spaces, leading many of them to not only vocalize their appreciation of the nature, but also to increasingly utilize and enjoy these natural spaces since the flood.

\section{Environmental Uncertainty: Instability and Toxicity}

Finally, High River residents discuss the ways that the flood impacted the landscape, disrupted their feelings of security, and led to environmental toxicity. According to several residents, alterations to the landscape as a result of the flood, along with the new realization of the river's potential for flooding, results in them feeling unsafe and insecure. For example, Meagan describes how the flood reconfigured the river, altering her understanding of her surroundings. This changing landscape is concerning as it makes future flood patterns unpredictable. Megan states "Well, and I think now, after the flood, that the flood changed the landscape. So now I don't know that you can predict flood patterns because it changed the landscape. So, everything we thought we knew, and could prepare for, I don't think is." 
Similarly, Leanne discusses how the 2013 flood altered her ability to forecast extreme events, which is concerning for her.

"Well, and some people make comments in the town about how the river is a different entity now. It has changed, and so we don't know what to expect anymore because we knew you know, how the river would react to floods before, but because of the gouging, and the change of the river, the widening, the deepening, you know, all of those things, the silt that exists in certain areas... That people are afraid because they really don't know that if a huge flood comes again, even one comparable to like 1995, 2005, that it is going to be the same as then? They don't think it will be just because the river is not the same river anymore" (emphasis added).

This comment that "the river is not the same anymore" is particularly illustrative, for two reasons. First, following the flood, disaster remediation giant Tervita scalped and dredged the Highwood River to increase the river's capacity, to improve the flow of the river, and to mitigate future flood risk. Since the 2013 flood, more than 60,000 cubic meters of material have been removed from the river (Town of High River 2015). In this sense, the river is indeed different now. But, more importantly, the comment also suggests that residents no longer view the river the same way they did prior to the flood. Before the flood, residents knew the extent of possible flooding from the river and had some confidence in that extent, but after the flood, that was no longer the case. As Sagan (1993) writes, "things that have never happened before happen all the time," and the magnitude of the 2013 flood shattered confidence in those past experiences for residents. For them, the river can no longer be predicted. Consequently, as Burningham, Fielding, and Thrush (2008) point out, residents with past disaster experience are often unprepared for future floods; they use their experience to assess future possibilities, and sometimes they are wrong. This is clearly the case for High River residents who, as a result of a lack of awareness of the future predictability of floods, feel insecure in the environment in 
which they live. More broadly, this observation also connects to the work of Hawkins and Maurer (2011) who point out the tendency for disaster to rupture residents' confidence in a secure, stable, and predictable environment.

Another way that the participants discuss their feelings of lack of safety, security, and stability in their environmental milieu, is by discussing their concern about the potential contamination of their surroundings. Prior research in the context of Hurricane Katrina and other disasters reveals that environmental testing simply cannot answer the fundamental question that residents want answered: Are we safe here? The resulting system of "organized ignorance" (Frickel and Vincent 2007) leaves residents in limbo; is returning to a flooded home or community jeopardizing one's health? Results of this study indicate significant and lingering about environmental toxicity and health among residents in the aftermath of the flood. Residents' concern about the safety of their environment is illustrated by the following statement by Cassandra: "Should we be here? You know, they tell us it's safe, but when there's houses still sitting that nothing has been done [since the flood], how safe is that?"

Others worry that the myriad contaminants that washed up and floated during the flood could combine into a mixture that is hazardous to residents' health. As Juliet recalls:

"The thing that was horrifying to me was, after the flood, you know, the roast that was floating in the basement... for four weeks, along with the paint that was in the laundry room, along with the nail polish remover that was in the bathroom. Like, all of those things, together in the environment, now that's something that I think about and pay attention to and wonder about."

Like New Orleanians who referred to their contaminated city as "our toxic gumbo" (Frickel and Vincent 2007), High River residents wonder about the toxic combination of 
rotting food, chemicals, debris, and other refuse, as well as what traces of those contaminants may remain on their property or in their homes.

Residents are not only concerned about the contaminants that were spread during the flood, but also about the speed of remediation that took place after the flood. Many residents discuss how remediation was done very quickly so that residents could get back into their homes, but that this often meant sloppy or incomplete work and, logically, possible lingering contamination that has impacted and may continue to affect the health of residents post-flood. As Brianna points out:

"If you just look at some of the homes that have been damaged, even half the homes that were remediated, rebuilt, and people moved into, and then there's... they find mold, or any kind of, like some fairly serious environmental issues in their home they have to move out again..... There's some people who are really directly impacted and other people that just have sore throats, or constant nose running, and they just don't really know why. And then there's other people that were really, really sick."

Like other participants, Brianna professes a lack of knowledge about the true safety of residents in the aftermath of the flood. She also states "Nobody really knows, there is not a lot of information or testing, or, just that communication piece again. What is happening, and what will people be up against long term?” Echoing Frickel and Vincent's (2007) argument, Brianna suggests that residents worry about the temporality of contamination. In other words, if testing is in fact being done, those tests can only show levels of a few compounds or microorganisms at one point in time. This raises an important question of concern for many residents: How will exposure to contaminants matter for our health over a period of many years? This is simply not a question that postdisaster environmental testing is calibrated to answer. 
Many residents are specifically concerned about the contamination of the environment in relation to both the air quality and the safety of the soil. They worry about the quality of the air that they breathe and the impact it has on their health. For example Tina discusses how many people within the town became ill after the flood, and worries that it relates to contaminants in the air. Tina indicates,

"I heard a lot of comments about people not feeling well...I thought of what was in the air post-flood? People making comments like, 'I never get sick, but I've been sick frequently since working in High River, or Saddlebrooke.' So, that...made me think, I wonder what kind of testing is happening."

Tina's comment illustrates that, not only are residents unaware about their safety in the town, but they are not even made aware about what kinds of testing have taken place, a finding consistent with previous research in post-disaster environments (Frickel and Vincent 2007; Shriver et al. 2014).

Residents also question the safety of the soil and the impact it has on their health. For example, Kristin worries that the condemned and abandoned homes within the town will pose risks by contaminating the soil.

"When you drive down the street and there's still a lot of abandoned houses with the signs on the window saying that they're uninhabitable, for me I just wonder if those houses are sitting there rotting, or mold, or asbestos, or whatever is living in them, that's got to be going somewhere. So is it going into the ground? Is it in the air? I wonder when somebody is going to decide if they need to be torn down and get it done... or have those pets removed. So that's a concern for me."

Similarly, Cassandra mistrusts the soil that she had previously been told was safe, but later learned was not safe. According to Cassandra, "Every day, like they're ripping up the boulevards [area between sidewalk and curb] and I'm like, why are you taking that grass away? You told me my grass is safe and now I'm thinking, is it safe if you're ripping up that?" 
The current running through these accounts of environmental toxicity is one of doubt-- residents suspect that their surroundings may be contaminated, but can not be sure. They are, by and large, not aware of any environmental testing taking place, and even if it is taking place, they do not entirely trust the results. Though residents gained a new appreciation for the natural environment (as discussed above), this uncertainty over possible contamination limits their ability to engage with their environment and enjoy green space. As Leanne reveals,

"In the sense of awareness of the toxicity around us, concerned about that. There was a lot of physical ailments that happened with people who had been in the flood waters and now they have to change their job because they got a virus or bacteria in a small cut and then almost lost a limb because of that. Even just wanting to work in your garden, do you really want to do that? I know that the sun kills it, and our winter, but there's still that, so you know, and all it takes is a little smell that you catch that's still in certain areas of your home that kind of set you off like in the garage or where ever, there's a certain smell there that yeah, takes you back."

Though gardening has been undertaken in other disaster-affected locales as a way to cope, as a form of political action, and as a method of increasing community resilience (Kato et al. 2013), the inability for High River residents to obtain clear answers about ongoing environmental risks, overall, limits them from engaging with their environment.

\section{CONCLUSION}

Experiencing the flood prompted the High River residents we interviewed to think about, and at times, interact with the environment in new and different ways. First, residents began to consider the effects of human activity on the environment, and how human human actions like the siting of new homes and clear-cutting of forests place residents at risk and elevate flood risk. Second, residents developed a new appreciation for nature, both for the sheer power and incorrigible will of the natural environment, and in terms of 
spending more time and using the natural environment as a venue for recreation. Third, experiencing the flood disrupted High River residents' ontological security (Hawkins and Maurer 2011), both because the flood challenged their preconceived ideas of the river's potential, and also because of continued worry over a toxic, contaminated environment. However, experiencing the flood did not change residents' overall thoughts about the environment, nor did it translate into residents living in more environmentally sustainable ways. As one participant, Ryan indicates,

It [the flood] isn't an issue that seems to have changed- people's perceptions of climate change...Kids and parents who didn't think it [climate change] was a big deal before, still don't think it' a big deal. Parents and kids who thought it was a big deal before maybe think it's a little bit more of a big deal. But it didn't seem to change anyone's position on it.

The findings thus reveal that residents voiced their newly-focused environmental views in more nuanced ways. As a result of experiencing the flood, they began to contemplate how human actions related to land development and engineering may contribute to larger environmental problems, such as disasters. This attribution of responsibility to humans results in feelings of blame, a dynamic frequently observed following technological disasters (Burgess 2012; Gill and Picou 1998; Mcspirit et al. 2016). However, residents struggle to describe their relationship to their surroundings, often stuttering or back-tracking in their analyses of it and suggesting a lack of familiarity in discussing environmental issues.

Findings from this study also contribute to the literature within environmental sociology on the conditions under which attitudinal change occurs. Although some theory suggests that change happens swiftly following watershed events (York and Clark 2006), our results are more in line with Bishop (2014), who identifies the 2010 BP oil 
spill as a "focusing event" - one that attracts renewed attention on human vulnerabilities and environmental change, but at the same time, also provides opportunity for affected residents to create new discursive fames and justifications for inaction. The flood did not radically change the views or practices of High River residents, but served to sensitize them to environmental risk and uncertainty, often by providing them new context for conversations had long before the flood. Though Bishop finds that the BP oil spill stoked feelings of protectionism of the oil industry by local residents, many of whom worked in the industry, our participants did not speak much about fossil fuel, despite its economic centrality to Alberta. We find instead that experiencing the flood made residents voice concern over development decisions, environmental stewardship, and the production of risk. None of them, however, articulated avenues or strategies for achieving these outcomes. Although residents did give voice to concerns about the influence of the homebuilding industry over municipal land-use decisions (Tierney 2014), they also failed to articulate any concrete strategies to encourage a more collaborative or communitydriven approach to land-use decision-making. Participants view environmental risk as a problem too entrenched to address with any concrete action. Even though some research (Spence et al. 2011) does find that experiencing a disaster translates into a greater wiliness to save energy and/or mitigate climate change, our findings are more consistent with those of Norgaard (2011) who concludes that awareness often fails to translate into concrete actions.

We explain this lack of action and mobilization in three ways: (1) Residents fail to connect the flood to processes of global climate change, and therefore to larger, national and global environmental movements. They also spend little time thinking about these 
distant, global problems (see also Barr 2008); (2) Residents experience feelings of helplessness in the face of the flood and even future floods, due to a lack of tools and resources to engage in environmentally sustainable practices; and (3) Residents are uncertain about possible contamination of the land post-flood, which limits their ability to engage with their environment. Examining residents' views of environmental change is particularly salient given that Alberta is home to one of the largest oil fields in the world, and previous research demonstrates how Alberta's dependence on this resource-based economy significantly shapes the political, economic, and social discourses in the province, prompting both public opinion and public policy to prioritize economic growth over environmental safeguards and precautions (Davidson and Haan 2011; Davidson and MacKendrick 2004; Parkins and Davidson 2008).

These findings have important implications for environmental policy because public risk perceptions of human impacts on the environment are "components of the socio-political context within which policy makers operate", and can "compel or constrain political, economic, social, and individual action" to address environmental hazards (Leiserowitz 2006). In this sense, public acceptance or rejection to environmental policies, such as climate change policies, are impacted by public perceptions of whether or not human actions impact the environment, and whether or not such efforts are even worthy of attention and efforts. Indeed these findings highlight the need for social scientists, governmental representatives, and environmental groups to provide people with greater knowledge of how to mitigate household-level disaster risk, how to engage with wider environmental issues, and how to secure better information about environmental health. Having said this, High River residents did voice a desire for 
a political system that privileges safety over economic development, a venue for engaging with larger environmental issues, such as clear-cutting practices, and a closer relationship to scientists who might determine if their land continues to be contaminated. In this context, we believe that giving people these educational initiatives, tools and resources, and increasing research that uncovers possible avenues for environmental change, will ultimately be key for enhancing post-disaster resilience.

\section{REFERENCES}

Alberta Emergency Managemet Agency [AEMA]. 2014. Emergency Planning: Lessons from High River 2013 Flood. Retrieved (http://www.aema.alberta.ca/documents/ema/A1_Emergency_Planning_Lessons_fro m_High_River_2013_Flood.pdf).

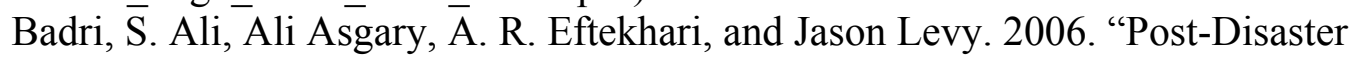
Resettlement, Development and Change: A Case Study of the 1990 Manjil Earthquake in Iran.” Disasters 30(4):451-68. Retrieved June 20, 2016 (http://doi.wiley.com/10.1111/j.0361-3666.2006.00332.x).

Barr, Stewart. 2008. Environment and Society: Sustainability, Policy, and the Citizen. Aldershot, UK: Ashgate.

Bell, S. E. and Y. a. Braun. 2010. "Coal, Identity, and the Gendering of Environmental Justice Activism in Central Appalachia." Gender \& Society 24(6):794-813.

Bell, Shannon Elizabeth. 2013. Our Roots Run Deep as Ironweed: Appalachian Women and the Fight for Environmental Justice. University of Illinois Press.

Bell, Shannon Elizabeth. 2016. Fighting King Coal: Challenges to Micromobilization in Central Appalachia. Cambridge: MIT Press.

Bell, Shannon Elizabeth and Richard York. 2010. "Community Economic Identity: The Coal Industry and Ideology Contruction in West Virginia." Rural Sociology 75(1):111-43.

Bishop, Bradford H. 2014. "Focusing Events and Public Opinion: Evidence from the Deepwater Horizon Disaster." Political Behavior 36(1):1-22.

Browne, Katherine E. and Lori Peek. 2014. "Beyond the IRB: An Ethical Toolkit for Long-Term Disaster Research." International Journal of Mass Emergencies and Disasters 31(3).

Bullard, Robert D. 1990. Dumping in Dixie: Race, Class, and Environmental Quality. Boulder: Westview Press.

Burawoy, Michael et al. 1991. Ethnography Unbound: Power and Resistance in the Modern Metropolis. Berkeley: University of California Press.

Burgess, Adam. 2012. 'Media, Risk, and Absence of Blame for 'Acts of God': 
Attenuation of the European Volcanic Ash Cloud of 2010." Risk Analysis 32(10):1693-1702.

Burningham, Kate, Jane Fielding, and Diana Thrush. 2008. “'It' L1 Never Happen to Me': Understanding Public Awareness of Local Flood Risk." Disasters 32(2):21638.

Cable, Sherry and Charles Cable. 1995. Environmental Problems, Grassroots Solutions: The Politics of Grassroots Environmental Conflict. New York: St. Martin's Press.

Canadian Broadcasting Corporation [CBC]. 2013. "Alberta Floods Costliest Natural Disaster in Canadian History." Retrieved

(http://www.cbc.ca/news/canada/calgary/alberta-floods-costliest-natural-disaster-incanadian-history-1.1864599).

Canadian Broadcasting Corporation. 2015. "Only 2\% of Canadians Deny Climate Change, Suggests Poll.” Retrieved (http://www.cbc.ca/news/canada/calgary/only-2of-canadians-deny-climate-change-suggests-poll-1.1157215).

Catton, W. R. and R. E. Dunlap. 1980. "A New Ecological Paradigm for Post-Exuberant Sociology." American Behavioral Scientist 24(1):15-47.

Chang, Stephanie E. 2010. "Urban Disaster Recovery: A Measurement Framework and Its Application to the 1995 Kobe Earthquake." Disasters 34(2):303-27. Retrieved June 20, 2016 (http://doi.wiley.com/10.1111/j.1467-7717.2009.01130.x).

Davidson, Debra J. and Michael Haan. 2011. "Gender, Political Ideology, and Climate Change Beliefs in an Extractive Industry Community." Population and Environment 34(2):217-34. Retrieved July 28, 2015 (http://link.springer.com/10.1007/s11111011-0156-y).

Davidson, Debra J. and Norah a MacKendrick. 2004. "All Dressed up with Nowhere to Go: The Discourse of Ecological Modernization in Alberta, Canada." Canadian Review of Sociology \& Anthropology 41(1):47-65.

Davidson, Debra J. and Norah A. MacKendrick. 2004. "All Dressed Up with Nowhere to Go: The Discourse of Ecological Modernization in Alberta, Canada." Canadian Review of Sociology/Revue canadienne de sociologie 41(1):47-65. Retrieved August 25, 2015 (http://doi.wiley.com/10.1111/j.1755-618X.2004.tb02169.x).

Drabek, Thomas E. 2011. Human System Responses To Disaster: An Inventory of Sociological Findings. New York: Springer.

Dunlap, Riley E. and Robert J. Brulle. 2015. Climate Change and Society: Sociological Perspectives. New York: Oxford University Press.

Dunlap, Riley E. and W. R. Catton. 1979. "Environmental Sociology." Annual Review of Sociology 5(1):243-73. Retrieved (http://www.annualreviews.org/doi/abs/10.1146/annurev.so.05.080179.001331).

Edelstein, Michael R. 2004. Contaminated Communities: Coping with Residential Toxic Exposure. 2nd ed. Boulder, CO: Westview Press.

Elliott, James R. 2015. "Natural Hazards and Residential Mobility: General Patterns and Racially Unequal Outcomes in the United States." Social Forces 93(4):1723-47.

Erikson, Kai. 1976. Everything in Its Path: Destruction of Community in the Buffalo Creek Flood. New York: Simon and Schuster.

Freudenburg, William R., Scott Frickel, and Robert Gramling. 1995. "Beyond the Nature/Society Divide: Learning to Think About a Mountain." Sociological Forum 10(3):361-92. 
Freudenburg, William R., Robert Gramling, Shirley Laska, and Kai T. Erikson. 2008. "Organizing Hazards, Engineering Disasters? Improving the Recognition of Political-Economic Factors in the Creation of Disasters." Social Forces 87(2):101538. Retrieved (http://sf.oxfordjournals.org/content/87/2/1015\nhttp://sf.oxfordjournals.org/content/ 87/2/1015.short).

Freudenburg, William R., Robert Gramling, Shirley Laska, and Kai T. Erikson. 2009. "Disproportionality and Disaster: Hurricane Katrina and the Mississippi River-Gulf Outlet." Social Science Quarterly 90(3):497-515.

Frickel, Scott and M. Bess Vincent. 2007. "Hurricane Katrina, Contamination, and the Unintended Organization of Ignorance." Technology in Society 29(2):181-88.

Fussell, Elizabeth, Narayan Sastry, and Mark Vanlandingham. 2010. "Race, Socioeconomic Status, and Return Migration to New Orleans after Hurricane Katrina." Population and Environment 31(1-3):20-42.

Giddens, Anthony. 1990. The Consequences of Modernity. Cambridge: Polity.

Giddens, Anthony. 1991. Modernity and Self-Identity: Self and Society in the Modern Age. Cambridge: Polity.

Gill, Duane and J. Steven Picou. 1998. "Technological Disaster and Chronic Community Stress." Society \& Natural Resources 11(8):795-815.

Gould, Kenneth A. and Tammy L. Lewis, eds. 2015. Twenty Leassons in Environmental Sociology: An Introduction to Environmental Sociology. New York: Oxford University Press.

Government of Canada. 2016. Estimate of the Average Annual Cost for Disaster Financial Assistance Arrangements due to Weather Events. Ottawa. Retrieved (http://www.pbodpb.gc.ca/web/default/files/Documents/Reports/2016/DFAA/DFAA_EN.pdf).

Haden, Van R., Meredith T. Niles, Mark Lubell, Joshua Perlman, and Louise E. Jackson. 2012. "Global and Local Concerns: What Attitudes and Beliefs Motivate Farmers to Mitigate and Adapt to Climate Change?" PLoS ONE 7(12).

Hamilton, Lawrence C., Thomas G. Safford, and Jessica D. Ulrich. 2012. "In the Wake of the Spill: Environmental Views Along the Gulf Coast." Social Science Quarterly 93(4):1053-64.

Haney, Timothy J. and James R. Elliott. 2013. "The Sociological Determination : A Reflexive Look at Conducting Local Disaster Research after Hurricane Katrina." Sociology Mind 3(1):7-15.

Harmon, S. M. and D. E. Wyatt. 2008. "Evaluation of Post-Katrina Flooded Soils for Contaminants and Toxicity to the Soil Invertebrates Eisenia Fetida and Caenorhabditis Elegans." Chemosphere 70(10):1857-64.

Hawkins, Robert L. and Katherine Maurer. 2011. "You Fix My Community, You Have Fixed My Life': The Disruption and Rebuilding of Ontological Security in New Orleans." Disasters 35(1):143-59.

Johnson, Dominic and Simon Levin. 2009. “The Tragedy of Cognition: Psychological Biases and Environmental Inaction." Current Science 97(11):1593-1603.

Kato, Y., C. Passidomo, and D. Harvey. 2013. "Political Gardening in a Post-Disaster City: Lessons from New Orleans." Urban Studies (July 2013):1-17. Retrieved (http://usj.sagepub.com/cgi/doi/10.1177/0042098013504143). 
Kato, Yuki. 2013. "Not Just the Price of Food: Challenges of an Urban Agriculture Organization in Engaging Local Residents." Sociological Inquiry 83(3):369-91.

Klinenberg, E. 2002. Heat Wave: A Social Autopsy of Disaster in Chicago. University of Chicogo Press.

Kroll-Smith, J. and S. Couch. 1993. "Symbols, Ecology, and Contamination: Case Studies in the Ecological-Symbolic Approach to Disaster." Research in Social Problems and Public Policy 5:47-73.

Kroll-Smith, J. Stephen and Stephen R. Couch. 1993. "Technological Hazards: Social Responses as Traumatic Stressors." Pp. 79-91 in International Handbook of Traumatic Stress Syndromes, edited by J. P. Wilson and B. Raphael. New York: Plenum Press.

Lefsrud, L. M. and R. E. Meyer. 2012. 'Science or Science Fiction? Professionals' Discursive Construction of Climate Change." Organization Studies 33(11):14771506. Retrieved (http://oss.sagepub.com/content/33/11/1477.full).

Leiserowitz, Anthony. 2006. "Climate Change Risk Perception and Policy Preferences: The Role of Affect, Imagery, and Values." Climatic Change 77(1-2):45-72.

Lerner, Steve. 2006. Diamond: A Struggle for Environmental Justice in Louisiana's Chemical Corridor. Boston: MIT Press.

Lerner, Steve. 2010. Sacrifice Zones: The Front Lines of Toxic Chemical Exposure in the United States. Cambridge: MIT Press.

Logan, John R. and Harvey Molotch. 1987. "The City as a Growth Machine: Toward a Political Economy of Place.” Pp. 50-98 in Urban Fortunes: The Political Economy of Place. Berkeley: University of California Press.

Malin, Stephanie A. 2015. The Price of Nuclear Power: Uranium Communities and Environmental Justice. New Brunswick, NJ: Rutgers University Press.

Marshall, Brent K., J. Steven Picou, and Christine A. Bevc. 2005. "Ecological Disaster as Contextual Transformation - Environmental Values in a Renewable Resource Community." Environment and Behavior 37(5):706-28. Retrieved ( $<$ Go to ISI>://WOS:000231221700006\nhttp://eab.sagepub.com/content/37/5/706).

Maxwell, Joseph A. 2005. Qualitative Research Design: An Interactive Approach. Thousand Oaks, CA: Sage.

Mcspirit, Stephanie, Sharon Hardesty, and Robert Welch. 2016. "Post Disaster Interviews with Martin County Citizens : ' Gray Clouds ' of Blame and Distrust.” Journal of Appalachian Studies 11(1/2):7-29.

Messer, Chris M., Thomas E. Shriver, and Alison E. Adams. 2015. "Collective Identity and Memory: A Comparative Analysis of Community Response to Environmental Hazards." Rural Sociology 80(3):314-39.

Miles, Matthew B. and A. Michael Huberman. 1994. Qualitative Data Analysis: An Expanded Sourcebook. Thousand Oaks, CA: Sage.

Mileti, Dennis. 1999. Disasters by Design: A Reassessment of Natural Hazards in the United State.

Mix, Tamara L. and Kristin G. Waldo. 2015. "Know(ing) Your Power: Risk Society, Astroturf Campaigns, and the Battle over the Red Rock Coal-Fired Plant." The Sociological Quarterly 56(1):125-51. Retrieved (http://doi.wiley.com/10.1111/tsq.12065).

Norgaard, Kari. 2011. Living in Denial: Climate Change, Emotions, and Everyday Life. 
Cambridge: MIT Press.

O’Connor, Robert E., Richard J. Bord, and Ann Fisher. 1999. "Risk Perceptions, General Environmental Beliefs, and Willingness to Address Climate Change." Risk Analysis 19(3):461-71. Retrieved June 20, 2016 (http://doi.wiley.com/10.1023/A:1007004813446).

Pais, J. F. and J. R. Elliott. 2008. "Places as Recovery Machines: Vulnerability and Neighborhood Change After Major Hurricanes." Social Forces 86(4):1415-53. Retrieved (http://sf.oxfordjournals.org/cgi/doi/10.1353/sof.0.0047).

Parkins, John R. and Debra J. Davidson. 2008. "Constructing the Public Sphere in Compromised Settings: Environmental Governance in the Alberta Forest Sector." Canadian Review of Sociology 45(2):177-96.

Picou, J. Steven. 2009. "Katrina as a Natech Disaster: Toxic Contamination and LongTerm Risks for Residents of New Orleans." Journal of Applied Social Science 3(2):39-55.

Picou, J. Steven, Brent K. Marshall, and Duane a Gill. 2004. "Disaster, Litigation , and the Corrosive Community "." Social Forces 82(June):1493-1522.

River, Town of High. 2015. "Dredging Versus Scalping - Part 1." Retrieved April 1, 2016 (http://www.highriver.ca/index.php/en/publicforums/news-forum/newsflash/714-dredging-versus-scalping-part-1-dredging-versus-scalping-part-1).

Rung, Ariane L., Stephanie T. Broyles, Andrew J. Mowen, Jeanette Gustat, and Melinda S. Sothern. 2011. "Escaping to and Being Active in Neighbourhood Parks: Park Use in a Post-Disaster Setting." Disasters 35(2):383-403.

Sagan, Scott. 1993. The Limits of Safety: Organizations, Accidents, and Nuclear Weapons. Princeton: Princeton University Press.

Shriver, T. E., a. E. Adams, and C. M. Messer. 2014. "Power, Quiescence, and Pollution: The Suppression of Environmental Grievances." Social Currents 1(3):275-92. Retrieved (http://scu.sagepub.com/lookup/doi/10.1177/2329496514540133).

Snider, Laureen. 2004. "Resisting Neo-Liberalism: The Poisoned Water Disaster in Walkerton, Ontario." Social \& Legal Studies 13(2):265-89.

Sodero, Stephanie and Mark C. J. Stoddart. 2015. "A Typology of Diversion: Legitimating Discourses of Tourism Attraction, Oil Extraction and Climate Action in Newfoundland and Labrador." Environmental Sociology 1(1):59-68. Retrieved (http://www.tandfonline.com/doi/abs/10.1080/23251042.2014.1002186).

Spence, A., W. Poortinga, C. Butler, and N. .. Pidgeon. 2011. "Perceptions of Climate Change and Willingness to Save Energy Related to Flood Experience." Nature Climate Change 1:46-49.

Tidball, Keith G. 2012. "Urgent Biophilia: Human-Nature Interactions and Biological Attractions in Disaster Resilience." Ecology and Society 17(2):5-23.

Tierney, Kathleen. 2014. The Social Roots of Risk: Producing Disasters, Promoting Resilience. Palo Alto, CA: Stanford University Press.

Walters, A. Brooke et al. 2014. "Getting Active in the Gulf: Environmental Attitudes and Action Following Two Mississippi Coastal Disasters." Social Indicators Research 118(2):919-36. Retrieved (http://link.springer.com/10.1007/s11205-013-0428-2).

Weber, Elke U. 2010. "What Shapes Perceptions of Climate Change?" Wiley Interdisciplinary Reviews: Climate Change 1(3):332-42.

Weber, Elke U. and Paul C. Stern. 2011. "Public Understanding of Climate Change in the 
United States." The American psychologist 66(4):315-28. Retrieved

(http://www.ncbi.nlm.nih.gov/pubmed/21553956).

York, Richard and Brett Clark. 2006. "Marxism, Positivism, and Scientific Sociology:

Social Gravity and Historicity." Sociological Quarterly 47(3):425-50. 